\title{
PENINGKATAN KESEJAHTERAAN RUMAH TANGGA NELAYAN MELALUI PENGELOLAAN DAN PENGEMBANGAN HASIL PERIKANAN DI MEULABOH PROVINSI ACEH
}

\author{
Yasrizal $^{1}$ \\ ${ }^{1}$ Program Studi Ekonomi Pembangunan Fakultas Ekonomi Uniververistas Teuku Umar \\ Koresponden : yasrizal@utu.ac.id
}

\begin{abstract}
ABSTRAK
Pemasalahan utuma tingginya tingkat kemiskinan masyarakat pesisir dikarenakan hasil perikanan tangkap yang dihasilkan langsung dijual kepengecel dan pedagang sehingga nilai yang diperoleh relatif rendah. Produksi hasil perikanan tangkap dapat meningkatkan pendapatan rumahtangga nelayanuntuk itu perlu dilakukan peningkatan skil tambahan bagi rumahtangga nelayan dalam melakukan pengolahan perikanan. Tujuan dari kegiatan ini adalah untuk meningkatkan tujuan kegiatan ini adalah melakukan transfer ilmu pengolahan hasil perikanan kepada rumah tangga nelayan dalam upaya meningkatkan pendapatan rumahtangga nelayan dan masyarakat pesisir. Metode kegiatan yang dilakukan adalah pelatihan yang berbentuk penjelasan materi pengolahan perikanan, pendampingan pengolahan hasil perikanan, pengemasan produk perikanan dan produksi hasil perikanan. Produk yang diolah adalah bakso dan naget yang terbuat dari ikan. Masyarakat Meulaboh terlihat antusias dalam kegiatan pengolahan hasil perikanan, ada upaya masyarakat untuk memproduksi hasil olahan perikanan.
\end{abstract}

Kata Kunci: Produk Perikanan, Peningkatan Ekonomi Rumahtangga, kualitas produk

\begin{abstract}
Abstract: The main problem is the high level of poverty in coastal communities due to captured fishery products being sold directly to retailers and traders so that the value obtained is relatively low. Production of capture fisheries products can increase fishermen's household income for that it is necessary to increase additional skills for fishermen households in processing fisheries. The purpose of this activity is to improve the purpose of this activity is to transfer the knowledge of processing fishery products to fishermen households in an effort to increase household income of fishermen and coastal communities. The method of activities carried out is training in the form of explanation of fisheries processing materials, fisheries product processing assistance, fishery product packaging and fishery products production. Products that are processed are meatballs and nagets made from fish. Meulaboh community looks enthusiastic in processing fishery products, there are community efforts to produce processed fishery products.
\end{abstract}

Keywords: Fishery Products, Household Economic Improvement, product quality

\section{PENDAHULUAN}

Indonesia merupakan salah satu negara kepulauan, memiliki garis pantai terluas. Banyak masyarakat yang hidup di pesisir pantai. Masyarakat pesisir menggantungkan hidupnya dengan sumberdaya pesisir. Secara ekonomi masyarakat pesisir masih terbelakang dan berada dalam posisi marginal. Masyarakat pesisir mempunyai cara berbeda dalam aspek pengetahuan, kepercayaan, peranan sosial, dan struktur sosialnya. Sementara itu, dibalik kemarginalannya, masyarakat pesisir tidak mempunyai banyak cara dalam mengatasi masalah yang hadir. Masalah kompleks yang dihadapi masyarakat pesisir adalah kemiskinan, keterbatasan 
pengetahuan untuk pengelolaan sumberdaya dan teknologi, serta peran aktif antara pihak luar dengan masyarakat pesisir sehingga dapat menghidupkan kualitas dan keterampilan masyarakat pesisir tanpa melunturkan karakter budayanya.

Masyarakat pesisir memerlukan bentuk kegiatan nyata yang dapat membangun ekonomi mereka tanpa menghilangkan kultur dan karakteristik dari masyarakat pesisir tersebut. Maka diperlukan suatu bentuk kegiatan yang berbasis masyarakat. Salah satu kegiatan yang dapat dilakukan adalah pemberdayaan masyarakat melalui pelatihan ketrampilan penanganan dan pengolahan hasil-hasil tangkapan nelayan yang memanfaatkan potensi sumberdaya hasil laut.

Pemanfaatan potensi sumberdaya hasil perikanan khususnya hasil laut belum banyak termanfaatkan secara optimal di masyarakat. Belum maksimalnya pemanfatan potensi sumberdaya alam tersebut disebabkan oleh masih terbatasnya informasi dan pengetahuan masyarakat dalam teknik pengolah hasil-hasil perikanan tersebut. Hal tersebut menyebabkan perkembangan perekonomian masyarakat pesisir sangat lambat. Kondisi ini dapat dilihat dari banyaknya desa-desa nelayan yang taraf kehidupan masyarakatnya yang cenderung menengah ke bawah.

Meulaboh merupakan ibu kota dari Kabupaten Aceh Barat. Salah satu kabupaten yang memiliki hasil tangkap ikan laut tertinggi di Aceh setelah Banda Aceh. Sebagian besar kepala rumah tangganya berprofesi sebagai petani dan nelayan, sedangkan ibu-ibu berprofesi sebagai ibu rumah tangga. Kondisi perekonomian masyarakat di Pesisir pantai Meulaboh masuk ke dalam kategori menengah ke bawah, sehingga diperlukan upaya peningkatan ekonomi rumah tangga melalui kegiatan pemberdayaan ibu-ibu PKK.

Kegiatan peningkatan ekonomi masyarakat melalui pengolahan produk berbasis hasil perikanan menjadi solusi dalam kegiatan tersebut, mengingat wilayah Aceh Barat merupakan salah satu Kabupaten yang terletak di sepanjang garis pantai wilayah Barat Aceh. Sehingga untuk memperoleh bahan baku hasil perikanan cukup mudah, bervariasi dan harga yang murah.

Permasalahan utama yang dihadapi oleh kelompok masyarakat pesisir ini adalah kurangnya pengetahuan dalam menangani hasil-hasil perikanan pasca tangkap serta kurangnya ketrampilan dalam mengolah hasil-hasil tangkapan khususnya pada saat hasil tangkapan melimpah. Hasil tangkapan yang tidak tertangani dapat menyebabkan terjadinya penurunan mutu yang sangat cepat sehingga nilai jualnya rendah. Disamping itu, hasil tangkapan yang melimpah biasanya hanya dibiarkan membusuk atau dibuang kembali ke laut. Hal ini menyebabkan perekonomian masyarakat tidak berkembang dari tahun ke tahun. Oleh sebab itu diperlukan suatu usaha pemberdayaan masyarakat pesisir untuk dapat meningkatkan ketrampilan dan pendapatan mereka. Dengan demikian, dalam kegiatan ini permasalahaan yang dapat dirumuskan :

Bagaimanakah ketrampilan mengolah ikan, khususnya dalam pembuatan bakso ikan dan nugget ikan dapat diberikan kepada ibu-ibu rumahtangga nelayan di Meulaboh Aceh Barat, Apakah dengan pembuatan produk olahan ikan akan meningkatkan kesejahteraan dan pendapatan bagi masyarakat Meulaboh Kabupaten Aceh Barat? 


\section{METODE KEGIATAN}

Kegiatan pelaksaan program Pengabdian Masyarakat di Meulaboh Aceh Barat terdiri dari dua tahapan, yaitu menjalin dan membentuk kemitraan dan memberikan pelatihan pembuatan produk-produk olahan hasil perikanan. Adapun produk yang diperkenalkan ke masyarakat yaitu, nugget ikan dan bakso ikan.

\section{Model Pemberdayaan Meulaboh Aceh Barat}

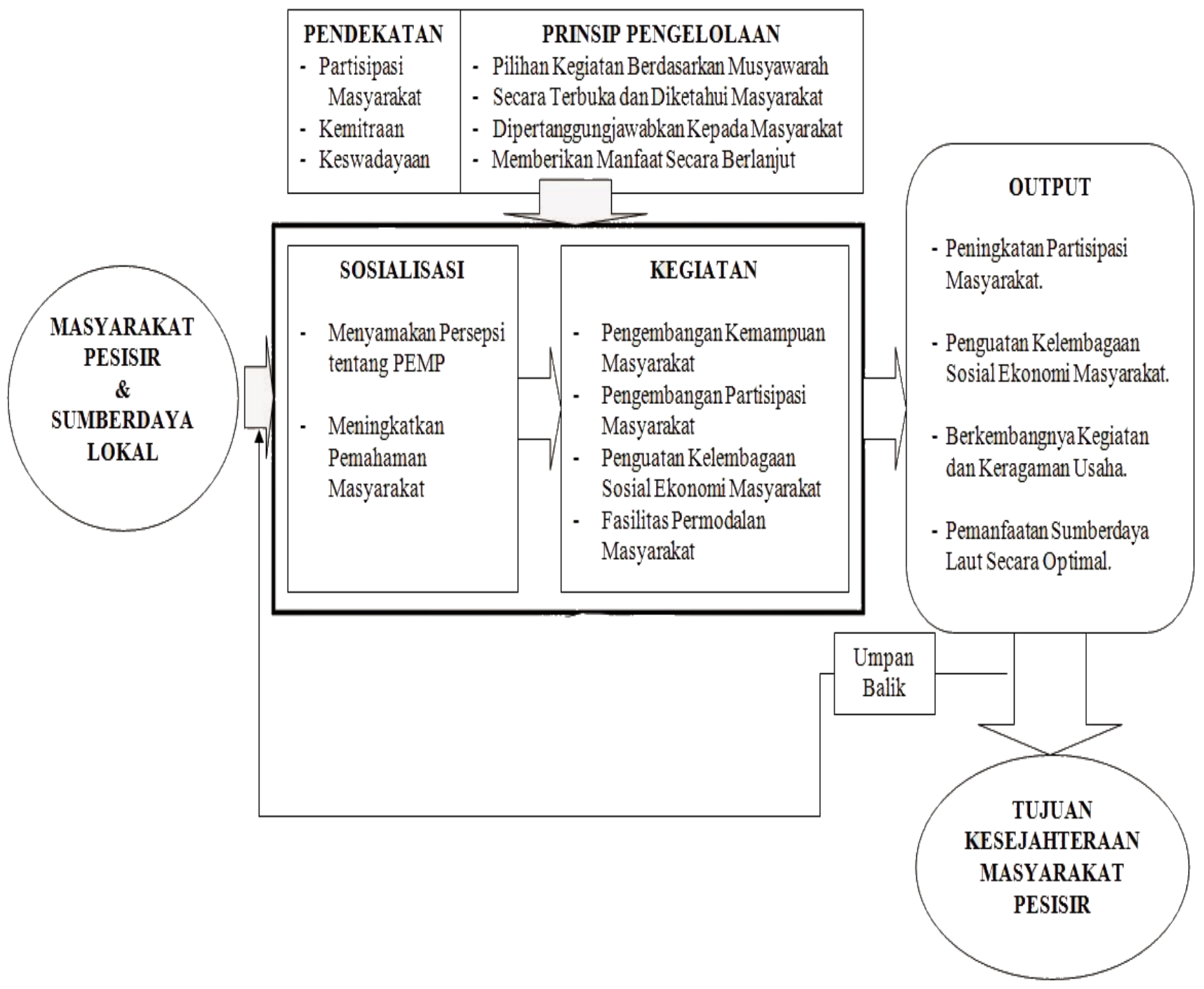

\section{Metode Penerapan Ipteks}

Kegiatan pelatihan pengolahan perikanan yang dilakukan menggunakan pendekatan pembelajaran orang dewasa. Metode yang digunakan adalah ceramah, tanyajawab dan praktek langsung pengolahan hasil perikanan.

a. Pendekatan ceramah dilakukan untuk memberikan pemahaman kepada khalayak sasaran tentang pentingnya melakukan pengolahan hasil perikanan untuk meningkatkan pendapatan masyarakat, ketersediaan bahan baku, produk yang berkualitas dan higienis serta enak dipandang mata. Khalayak sasaran 
akan diberikan pengetahuan tentang bagaimana membentuk jiwa kewirausahaan.

b. Pendekatan diskusi dilakukan untuk mendapatkan umpan balik tentang pengetahuan yang sudah diterima khalayak sasaran. Dari diskusi akan diperoleh informasi tentang sejauhmana pemahaman khalayak sasaran terhadap pengetahuan yang sudah diberikan.

Rancangan Evaluasi Dalam upaya untuk mencapai tujuan pelaksanaan kegiatan. Evaluasi meliputi indikator:

1. Pemahaman peserta terhadap materi yang diberikan.

2. Antusianisme dalam melakukan kegiatan.

3. Kejelasan materi yang diberikan.

4. Kemudahan dalam menerima materi.

5. Cara pemateri menyampaikan materi.

6. Meningkatkan kemampuan khalayak sasaran dalam manajemen usaha.

Kegiatan PPM ini dilakukan dengan melalui beberapa langkah meliputi:

a. Persiapan: koordinasi dengan mitra, penentuan waktu pelaksanaan, menjalin kerjasama denganmitra, penentuan tenaga ahli, komunikasi dan koordinasi dengan tenaga ahli, persiapan alat dan bahan yang dibutuhkan untuk pelatihan, publikasi/undangan kepada tenaga ahli dan administrasi.

b. Pelaksanaan : pelaksanaan kegiatan pengabdian dilakukan dengan melibatkan tenaga ahli dan mitra. Adapun pelatihan yang diberikan kepada mitra adalah tentang manajemen dan kewirausahaan. Selanjutnya mitra diberikan pula pelatihan yang terkait dengan manajemen usaha yaitu penentuan harga jual produk, penyusunan laporan keuangan/ pembukuan sederhana dan penyusunan rencana bisnis.

c. Evaluasi dan tindak lanjut: evaluasi terhadap peningkatan kemampuan mitra sebelum dan sesudah pelatihan.

Tingkat partisipasi mitra dalam pelaksanaan kegiatan ini sangat tinggi, hal ini terlihat dari antusiasnya mitra mengajak masyarakat di sekitar usaha untuk bersamasama mengikuti pelatihan yang akan dilaksanakan dengan melibatkan pula kelompok wanita tani sebagai penggerak kegiatan. 


\section{PEMBAHASAN}

\section{Karakteristik Jumlah Tangkapan Responden}

Hasil tangkapan merupakan salah satu faktor penting dalam meningkatkan pendapatan nelayan. Pada tabel 1 dibawah ini merupakan hasil tangkapan nelayan dalam sekali meulaut. Data yang diambil melalui pendekatan survey yang dilakukan kepada 30 responden nelayan yang ada di Meulaboh Kabupaten Aceh Barat terutama di Pengoperasian Pangkalan Pendaratan Ikan (PPPI) Desa Ujong Baro Kabupaten Aceh Barat. Hasil yang diperoleh sangat bervariasil. Dapat dilihat pada tabel 1 di bawah ini:

Tabel 1. Distribusi Responden Menurut Modal

\begin{tabular}{ccc}
\hline Jumlah Tangkapan $(\mathrm{Kg})$ & Jumlah Responden & Prosentase $\%$ \\
\hline $0-20$ & 8 & $27 \%$ \\
$21-40$ & 16 & $53 \%$ \\
$41-60$ & 6 & $20 \%$ \\
\hline Jumlah & 30 & $100 \%$
\end{tabular}

Sumber: Data primer 2018

Tabel 4 menunjukkan bahwa hasil tangkapan nelayan Meulaboh bervariasi antara sesama nelayan. Dari hasil pengamatan peneliti terdapat 8 nelayan yang mendapatkan 0-20 Kg ikan, 16 Nelayan yang mendapatkan 21-40 Kg dan 6 Nelayan yang mendapatkan 41-60 Kg hasil tangkapan ikan. Dapat disimpulkan bahwa 27\% nelayan mendapatkan $0-20 \mathrm{Kg}$ hasil tangkapan sehari melaut, 53\% nelayan mendapatkan $21-40 \mathrm{Kg}$ ikan hasil tangkapan dan $20 \%$ nelayan mendapatkan ikan hasil tangkapan ikan sejumlah $41-60 \mathrm{Kg}$.

\section{Responden Menurut Pendapatan}

Tingkat pendapatan yang diperoleh nelayan dalam satu hari sangat bervariasi. Perbedaan pendapatan diantara nelayan sangat dipengaruhi oleh produktifitas nelayan. Hal tersebut disebabkan oleh beberapa faktor atau variabel bebas dalam model penelitian. Berikut data pendapatan nelayan Desa Meulaboh yang diperoleh dari hasil observasi:

Tabel 1. Distribusi Responden Menurut Pendapatan

\begin{tabular}{|c|c|c|}
\hline Pendapatan & Jumlah Responden & Prosentase \% \\
\hline $50.000-100.000$ & 10 & 33 \\
\hline $100.001-150.000$ & 15 & 50 \\
\hline $1500.001-200.000$ & 5 & 17 \\
\hline
\end{tabular}

Sumber:Data Primer diolah (september 2018)

Berdasarkan Tabel 1 dapat diketahui bahwa pada pendapatan nelayan dalam satu hari melaut. Pada kelompok pendapatan nelayan sebesar Rp. 50.000 sampai Rp 100.000 terdapat 10 nelayan atau 33\% dari jumlah responden. Pada kelompok pendapatan sebesar Rp. 100.001 sampai Rp 150.000 terdapat 15 orang nelayan atau 
50 \% dari jumlah responden. Pada kelompok pendapatan Rp 150.001 sampai dengan Rp 200.000 terdapat 5 orang nelayan atau $17 \%$ dari jumlah responden.

\section{Berbagai Produk Perikanan}

Kegiatan Pengabdian Kepada Masyarakat yang telah kami lakukan di Meulaboh, Kabupaten Aceh Barat, sangat diterima oleh masyarakat setempat, khususnya ibu-ibu PKK. Hal ini terlihat dari antusiasnya ibu-ibu mengikuti kegiatan samapai dengan selesai. Kegiatan ini dilaksanakan dibeberapa tempat seperti Desa Pu'uk dan Desa Langgung. Pemerintah desa sangat tertaik dalam kegiatan pengelohan hasil perikanan.
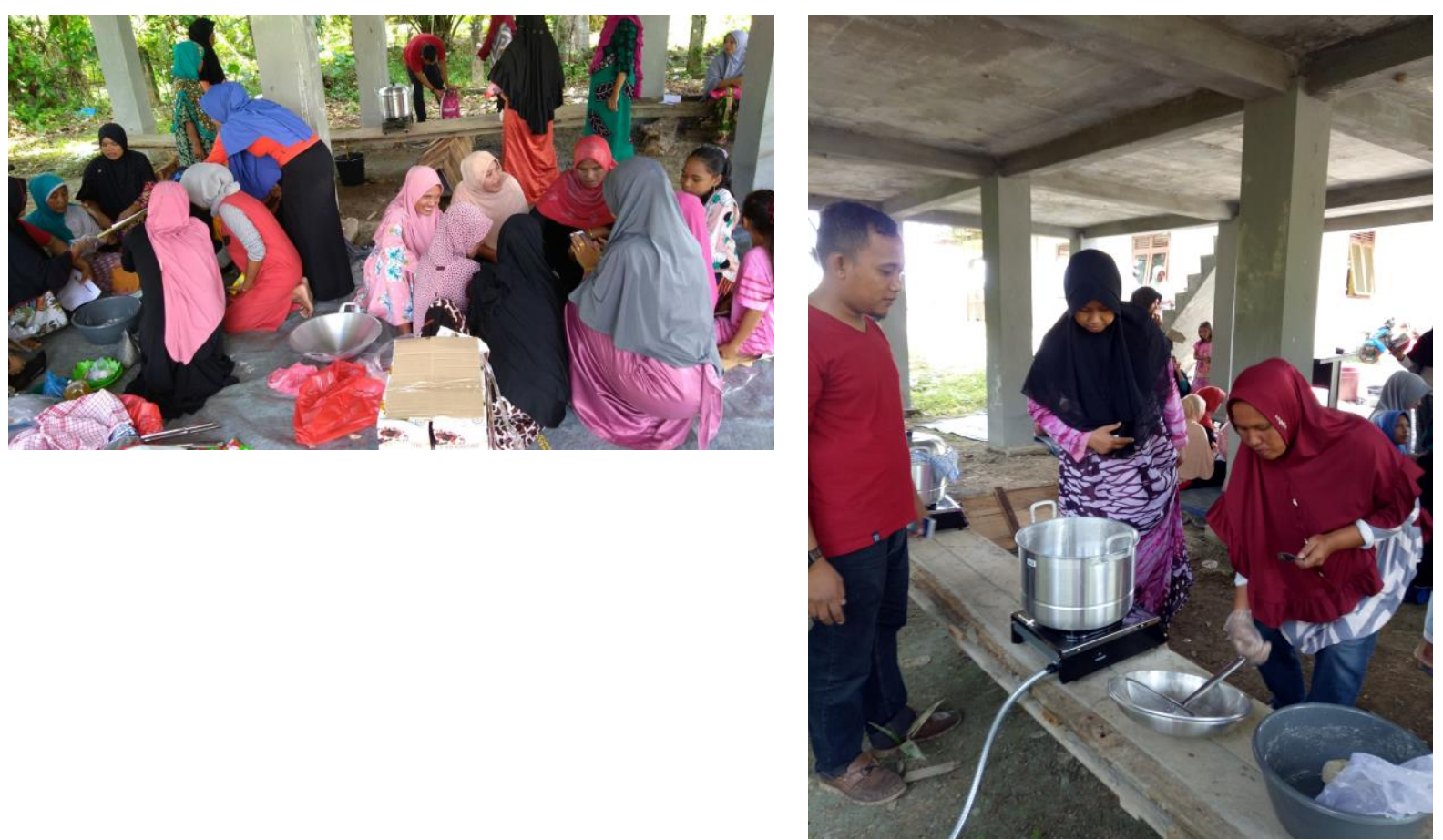

Keteranga: Ibu PKK di Meulaboh saat memberikan materi pengolahan ikan 2018

Selain praktek mengolah produk berbahan dasar ikan, masyarakat juga mendapatkan ilmu mengenai "Makan Ikan itu Sehat"dan analisis usaha produk, sehingga produk-produk yang telah diajarkan dapat diaplikasikan langsung membuat produk jajanan sehat untuk anak di rumah dan juga dapat menjadi sumber tambahan pendapatan rumah tangga dengan membuat usaha jajanan skala kecil di lingkungan sekolah maupun rumah.

Peningkatan ketrampilan masyarakat sangat diperlukan untuk memajukan perekonomian. Ketrampilan ini dapat berupa ketrampilan pengolahan produk makanan berbasis hasil laut dan pertanian, dapat pula ketrampilan non pangan. Sehingga ibuibu rumah tangga dapat mencari penghasilan tambahan. 


\section{a. Aspek Manajemen.}

Berdasarkan diskusi Mitra dapat memahami manajemen keuangan. Indikator memahami adalah mitra telah memisahkan keuangan usaha dan keuangan keluarga serta membuat neraca keuangan. Mitra cukup antusias dan berminat melakukan akses perbankan, untuk mendapatkan tambahan modal. Awalnya mitra belum membuat neraca keuangan, dengan alasan belum sempat dan perputaran keuangan relatif kecil. Dengan pembinaan secara

kekeluargaan dan menyampaikan peranan adanya neraca keuangan untuk melakukan refleksi dan evaluasi terhadap usaha yang dijalankan. Dengan pembinaan secara kontinu, mitra mau dan dapat membuat laporan atau neraca keuangan.

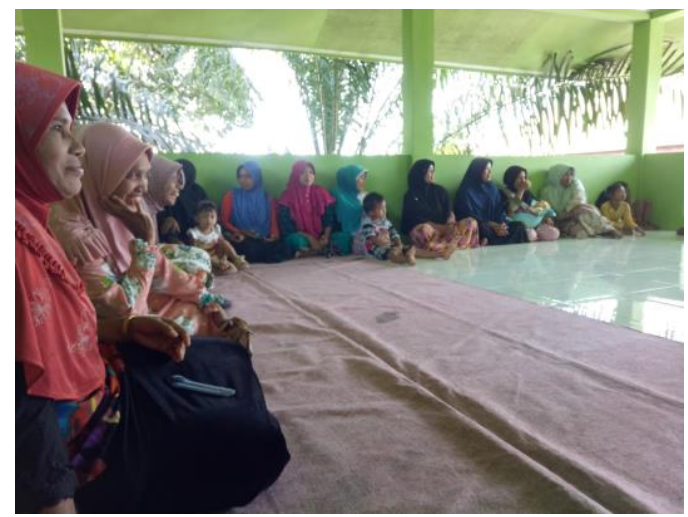

Keteranga: Ibu PKK di Meulaboh saat memberikan materi manajemen usaha 2018

\section{b. Kemasan Produk.}

Kegiatan pengamasan sangat penting dilakukan, karena mempu meningkatkan daya tahan produk dan daya tarik konsumen terhadap produk yang diproduksisetelah pengemasan kita berharap agar produk tersebut bisa memasuki beberapa swalayan yang ada di Meulaboh seperti sultan swalayan, zahwa dan indomaret. Adapun proses dan bentuk kemasan seperti berikut.

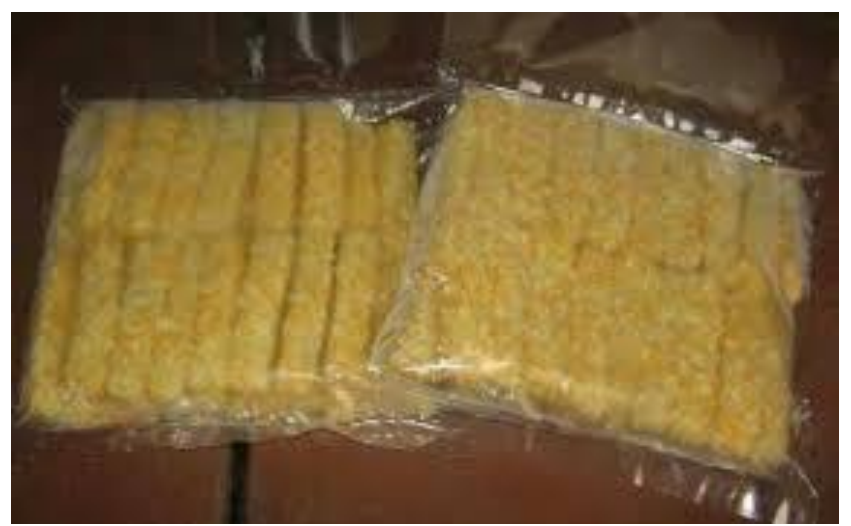

Keteranga: Hasil produk pengolahan produk perikanan yang dikemaskan 2018 


\section{c. Strategi Pemasaran}

Mitra masih melakukan strategi yang sederhana. Selain memasukkan produk ke swalayan, mitra juga menerima pesanan secara individu yang datang langsung ke mitra. Kita juga mengajarkan kepada mitra tentang pemasaran melalui online di media sosial seperti Whatsapp, Instagram, dan facebook. Hasil olahan bakso juga di tawarkan kepada berbagai warung mie bakso yang ada di seputaran meulaboh. Berdasarkan ceramah dan diskusi mitra termotivasi untuk memasarkan produknya dengan desain produk yang berbeda yaitu bakso dan naget yang berbeda dengan yang diproduksi. Untuk tahap realisasinya saat ini belum dilakukan mengingat mitra masih membutuhkan waktu untuk menemukan tekhnisi yang bisa membuat desain tersebut

\section{KESIMPULAN}

1. Melalui kegiatan pengolahan hasil perikanan menjadi bakso ikan dan naget ini dapat meningkatkan motivasi ibu-ibu rumah tangga, remaja putri dan Kelompok Usaha untuk menjadi wirausaha.

2. Melalui kegiatan pengolahan hasil perikanan menjadi produk makanan seperti bakso dan naget diharapkan rumah tangga nelayan yang sebelumnya menganggur dan tidak memiliki penghasilan tambahan, bisa

3. Kemampuan manajemen usaha kelompok untuk mengembangkan usaha produktif menunjukkan peningkatan

4. Pada aspek manajemen usaha dan pemasaran produk, mitra telah mampu

\section{DAFTAR PUSTAKA}

Adnyana, N.Retig, 2004. Kontribusi Network Terhadap Keunggulan Bersaing Dari Industri Kecil Sepatu, Tas dan Koper di Jawa Timur, Disertasi, Universitas Brawijaya Malang.

Astawa, I. P Mertha, 2006. Strategi Manajemen Sumber Daya Manusia, Orientasi Pasar dan kinerja UsahaKecil Menengah (Studi Pada Industri Kerajinan Ukiran Kayu di Kabupaten Gianyar Bali), Tesis, Universitas Brawijaya Malang.

Octavia, A. Haryadi, S. Rahayu dan Yulmardi,2012.Evaluasi Usaha Mikro Kecil dan Menengah Penerima Bantuan Pemerintah dan Strategi Peningkatan Daya Saing Usaha bersangkutan dalam rangka Mendorong Perekonomian Provinsi Jambi

Sulaeman, dan Suhendar, 2004. Pengembangan Usaha Kecil dan Menengah Dalam Menghadapi Pasar Regional dan Global,Infokop nomor 25 tahun XX.

Vitalaya, Aida, 2000. Tantangan dan prospek Teknologi Informasi dan Komunikasi dalam Otonomi Daerah, dalam Proseding Seminar Pemberdayaan Manusia Menuju Masyarakat Madani. Bogor, 25-26 September 2000. 